\title{
Kajian Mutu Bakso Ikan Tuna yang Disubstitusi Tepung Karagenan
}

\author{
Moon Ayu Kawanari Sitepu ${ }^{1 *}$, Hanny W.Mewengkang ${ }^{2}$, Daisy M. Makapedua ${ }^{2}$, Lena \\ Damongilala $^{2}$, Eunike Mongi ${ }^{2}$, Feny Mentang ${ }^{2}$, Verly Dotulong ${ }^{2}$ \\ ${ }^{1}$ Mahasiswa pada Program Studi Teknologi Hasil Perikanan \\ ${ }^{2}$ Staf Pengajar pada Program Studi Teknologi Hasil Perikanan \\ Fakultas Perikanan dan Ilmu Kelautan, Universitas Sam Ratulangi. \\ Jl. Kampus Unsrat Bahu, Manado 95115, Sulawesi Utara, Indonesia. \\ *Penulis Korespondensi: moonsitepu@gmail.com \\ (Diterima xx-01-2020; Direvisi xx-01-2020; Dipublikasi xx-01-2020)
}

\begin{abstract}
Fishball is a fish product that knows for their distinctive taste and chewy texture. The quality of fishball greatly affects the attractiveness of consumers to consume it, regarding the taste and aroma. The ingredients of fishball that have properties as an emulsifying is carrageenan. The purpose of this study was to determine the quality of tuna fishballs substituted with carrageenan flour with different concentrations and storage times. The treatment design used was RAL (completely randomized design) which consisted of 4 different concentration treatments of added carrageenan, for $0 \%, 1 \%, 2 \%$ and $3 \%$ with 2 days of storage and 2 times repetition. The quality parameters were organoleptic test, water content, $\mathrm{pH}$ and TPC (Total Plate Count). The results showed that the addition of carrageenan affected the water content and $\mathrm{pH}$ of fishballs. Tuna fishballs with the addition of a concentration of $2 \%$ are the best products with an average value of organoleptic values: 6.58 ; water content: 71.63 ; $\mathrm{pH}$ : 5.46 ; and TPC: $2.6 \times 10^{4}$. Water content in fishballl is not met SNI quality requirements. Total bacteria (TPC) in fishballs met SNI quality requirements.
\end{abstract}

Keywords: tuna fishballs, carrageenan.

Bakso ikan dikenal dengan rasanya yang khas dan teksturnya yang kenyal. Mutu kekenyalan bakso sangat mempengaruhi daya tarik konsumen untuk mengkonsumsinya selain rasa dan aroma. Bahan alami yang mempunyai sifat sebagai pengenyal adalah karagenan. Tujuan dari penelitian ini adalah untuk mengetahui mutu bakso ikan tuna yang disubstitusi tepung karagenan dengan konsentrasi dan waktu penyimpanan berbeda. Rancangan perlakuan yang digunakan adalah RAL (rancangan acak lengkap) yang terdiri dari 4 perlakuan konsentrasi berbeda penambahan karagenan yaitu $0 \%, 1 \%, 2 \%$ dan $3 \%$ dengan 2 hari lama penyimpanan dan 2 kali pengulangan. Parameter mutu yang diuji adalah uji organoleptik, uji kadar air, uji pH dan uji TPC (Total Plate Count). Hasil penelitian menunjukkan bahwa penambahan karagenan berpengaruh terhadap kadar air dan $\mathrm{pH}$ bakso ikan. Bakso ikan tuna dengan penambahan konsentrasi $2 \%$ merupakan produk yang terbaik dengan nilai rata-rata nilai organoleptik: 6,58; kadar air: 71,63; pH: 5,46; dan TPC: $2,6 \times 10^{4}$. Kadar air pada bakso tidak memenuhi persyaratan mutu SNI. Total bakteri pada bakso masih memenuhi persyaratan mutu SNI.

Kata kunci: bakso ikan tuna, karagenan.

\section{PENDAHULUAN}

\section{Latar Belakang}

Ikan mengandung zat gizi utama berupa protein, lemak, vitamin dan mineral (Junianto, 2003). Ikan memiliki kandungan air yang cukup tinggi, tubuh ikan menjadi media yang cocok untuk kehidupan bakteri pembusuk atau organisme lain, sehingga ikan sangat mudah mengalami proses pembusukan. Oleh karena itu, untuk mencegah pembusukan perlu dikembangkan berbagai cara pengawetan dan pengolahan yang cepat dan cermat agar sebagian besar ikan yang diproduksi dapat dimanfaatkan (Naa, 2011). Salah satu cara yang dapat dilakukan untuk memanfaatkan produksi perikanan adalah dengan diversifikasi produk hasil perikanan. Diversifikasi adalah cara yang diusahakan agar produk perikanan diolah menjadi beraneka ragam (Tendean, 2011). Melalui metode ini dapat meningkatkan daya serap pasar yang akan memproduksi dan akhirnya mendorong peningkatan pemanfaatan sumber daya perikanan secara optimal. Salah satu usaha diversifikasi produk hasil perikanan adalah pembuatan bakso. Bakso merupakan salah satu makanan khas Indonesia yang sangat populer dan cukup digemari. Bakso di Indonesia umumnya berbahan baku daging sapi, ayam dan ikan (Aziza et.al., 2015). 
Mutu kekenyalan bakso sangat mempengaruhi daya tarik konsumen untuk mengkonsumsinya selain rasa dan aroma. Bahan alami yang mempunyai sifat sebagai pengenyal adalah karagenan. Karagenan merupakan senyawa hidrokoloid hasil ekstraksi rumput laut jenis karaginofit seperti Eucheuma sp., Chondrus sp., Hypnea sp., dan Gigartina sp. Karagenan memiliki banyak manfaat, khususnya dalam industri makanan, diantaranya dapat berfungsi sebagai pembentuk gel, bahan penstabil, pengemulsi, pensuspensi, dan pendispersi (Anggadiredja et.al., 2006).

Karagenan berfungsi untuk memperbaiki tekstur bakso agar lebih kenyal dimana kekenyalan karagenan dalam membentuk gel dibedakan dari yang kuat sampai rapuh dengan tipe yang lembut dan elastis (Anggadireja, 2006). Selain sebagai pengeyal, penambahan karagenan dalam pembuatan bakso ikan juga diharapkan dapat menambah nilai gizi dan kandungan serat pangan pada produk.

\section{METODOLOGI PENELITIAN}

\section{Bahan dan Alat}

Bahan baku yang digunakan dalam penelitian ini adalah daging ikan tuna sirip kuning (Thunnus albacares) segar, sedangkan bahan tambahan adalah tepung tapioka, tepung karagenan dan es batu. Bumbu yang digunakan antara lain bawang merah, bawang putih, lada dan garam. Alat-alat yang digunakan antara lain: blender, homogenizer, timbangan, baskom, panci, kompor, saringan, sendok, pisau, sarung tangan plastik dan talenan.

\section{Metode dan Rancangan Perlakuan}

Metode yang digunakan dalam penelitian ini adalah metode eksperimental. Penelitian ini menerapkan rancangan acak lengkap yang disusun secara faktorial dan diulang sebanyak 2 kali percobaan. Rancangan perlakuan diterapkan dalam penelitian ini adalah sebagai berikut:

(1) Perlakuan A, substitusi bahan tambahan tapioka dengan tepung karagenan dalam 500 gr adonan bakso ikan, dengan tingkat faktor sebagai berikut:

$\mathrm{A} 0=10 \%$ tapioka $+0 \%$ tepung karagenan,

$\mathrm{A} 1=9 \%$ tapioka $+1 \%$ tepung karagenan,

$\mathrm{A} 2=8 \%$ tapioka $+2 \%$ tepung karagenan,

A $3=7 \%$ tapioca $+3 \%$ tepung karagenan.

(2) Perlakuan B, Lama penyimpanan pada suhu ruang dengan tingkat faktor:

$\mathrm{B} 0=0$ hari,

$\mathrm{B} 1=1$ hari.

\section{Tata Laksana Penelitian}

- Ikan tuna segar diperoleh dari pasar Bersehati dengan ukuran panjang berkisar antara 75-90 cm, dan rata rata berat satu ekor $800 \mathrm{gr}$.

- Ikan disiangi dengan cara dibuang kepala, insang, sisik dan isi perutnya, kemudian dicuci bersih dan ditiriskan.

- Kemudian ikan dibuat filet dan daging putih ikan dipisahkan dari daging merah dengan cara dikerok menggunakan sendok, kulit dan duri ikan dibuang.

- Pelumatan daging ikan dilakukan dengan menggunakan blender sampai diperoleh bentuk daging lumat yang homogen. Adonan bakso ikan tuna dibuat dengan menerapkan perlakuan A dengan komposisi konsentrasi karagenan.

- Kemudian ditambahkan bahan tambahan yaitu bumbu berupa bawang merah, bawang putih, lada, garam dan es batu.

- Pencetakan adonan digunakan dengan tangan dan menggunakan sarung tangan. Adonan dicetak atau dibentuk bulat dengan diameter kurang lebih $2 \mathrm{~cm}$ lalu selanjutnya bakso ikan direbus dalam air mendidih hingga mengapung lalu diangkat, kemudian ditiriskan.

\section{Parameter Yang Di Uji}

Parameter yang diamati dalam penelitian ini yaitu organoleptik, kadar air, $\mathrm{pH}$, dan TPC. 


\section{Analisa Data}

Data yang diperoleh dari uji organoleptik adalah data kuantitatif. Data kuantitatif adalah data dalam bentuk grafik. Data untuk uji organoleptik, uji kadar air, pH dan total bakteri yang diperoleh, ditentukan dengan mencari nilai rata-rata kemudian disajikan dalam bentuk grafik.

\section{HASIL DAN PEMBAHASAN}

\section{Uji organoleptik}

Rasa

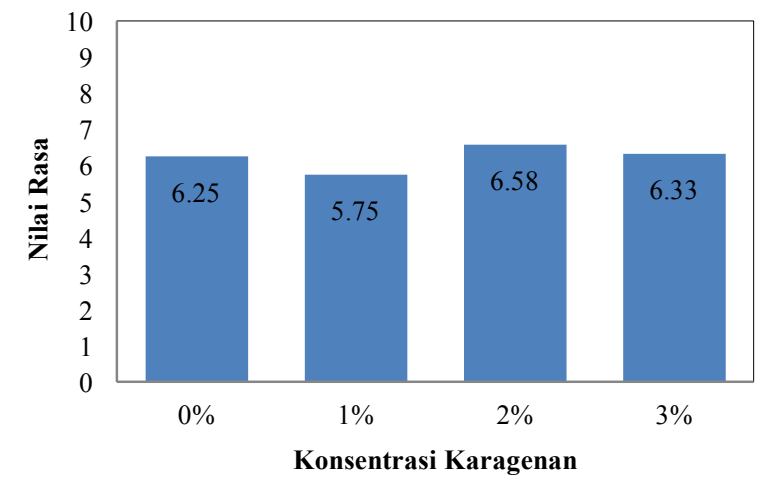

Gambar 1. Hasil penilaian panelis terhadap nilai organoleptik (rasa) bakso ikan tuna.

Berdasarkan Gambar 1, dapat dilihat bahwa penilaian panelis untuk produk bakso dengan citarasa terbaik ada pada bakso dengan substitusi karagenan 2\%. Selanjutnya bakso dengan substitusi karagenan 3\%. kemudian bakso tanpa tambahan karagenan dan yang terakhir bakso substitusi karagenan 1\%. Bakso yang paling disukai dari segi rasa adalah dengan konsentrasi 2\% karagenan. Dari segi rasa, tidak ada perbedaan yang jauh dari masing-masing penilaian karena menggunakan bahan baku dan pelengkap yang sama, hanya berbeda di konsentrasi karagenannya saja. Kriteria rasa bakso ikan menurut Wibowo (1999) ialah rasa yang lezat, rasa ikan dominan sesuai jenis ikan yang digunakan, dan rasa bumbu cukup menonjol tetapi tidak berlebihan. Dari grafik diketahui bahwa, rata-rata bakso mendapat nilai di atas 5 yaitu panelis bisa menerima rasa dari bakso yang diuji, namun nilai ini tidak memenuhi SNI yaitu rata-rata nilai 7 .

\section{Tekstur}

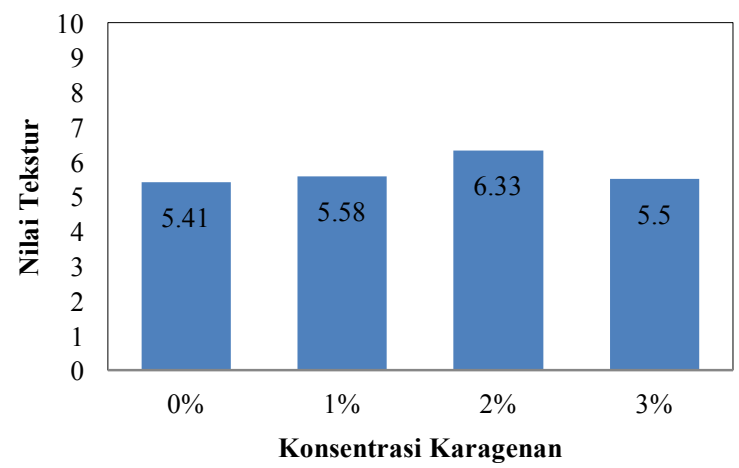

Gambar 2. Hasil penilaian panelis terhadap nilai organoleptik (tekstur) bakso ikan tuna.

Berdasarkan Gambar 2, dapat dilihat bahwa penilaian panelis untuk produk bakso dengan tekstur terbaik ada pada bakso dengan substitusi karagenan 2\%. Kemudian 2 yaitu bakso dengan substitusi karagenan 1\%. Selanjutnya bakso tanpa tambahan karagenan dan yang terakhir adalah bakso dengan substitusi karagenan 3\%. Nilai rata-rata 5-6 artinya penilaian panelis terhadap produk adalah netral - agak suka, namun nilai ini memenuhi SNI yaitu rata-rata nilai 7.

Penambahan karagenan dapat meningkatkan kekenyalan pada produk bakso. Winarno (1990) menyatakan karagenan mampu melakukan interaksi dengan makromolekul yang bermuatan, misalnya protein sehingga mampu mempengaruhi peningkatan viskositas, pembentukan gel, pengendapan dan stabilisasi. Pada produk bakso yang paling disukai panelis adalah dengan 
penambahan konsentrasi tepung karagenan sebanyak $2 \%$. Hal ini menunjukkan penambahan tepung karagenan berbanding lurus dengan peningkatan kekuatan gel bakso ikan tuna. Perbedaan kekuatan gel bakso ikan tuna yang dihasilkan untuk setiap perlakuan disebabkan oleh penambahan tepung karagenan. Kemampuan bakso untuk membentuk struktur yang kompak pada dasarnya disebabkan karena kemampuan daging untuk saling mengikat. Proses pengikatan ini disebabkan oleh panas. Karagenan pada daging dalam kondisi segar tidak menunjukkan kecenderungan untuk saling mengikat (Dwi 2008). Penambahan karagenan dengan konsentrasi yang pas dapat meningkatkan kekenyalan pada produk bakso. Hal ini sejalan dengan penelitian Ariffianto (2010) menyatakan bahwa karaginan dapat meningkatkan daya mengikat air sehingga dapat memperbaiki tekstur produk. Penambahan karagenan mempengaruhi tekstur suatu produk. Karagenan memberikan tekstur kenyal pada produk yang diolah, oleh karena itu penambahan karagenan dengan konsentrasi yang besar dapat menyebabkan tekstur suatu produk menjadi agak keras.

\section{Aroma}

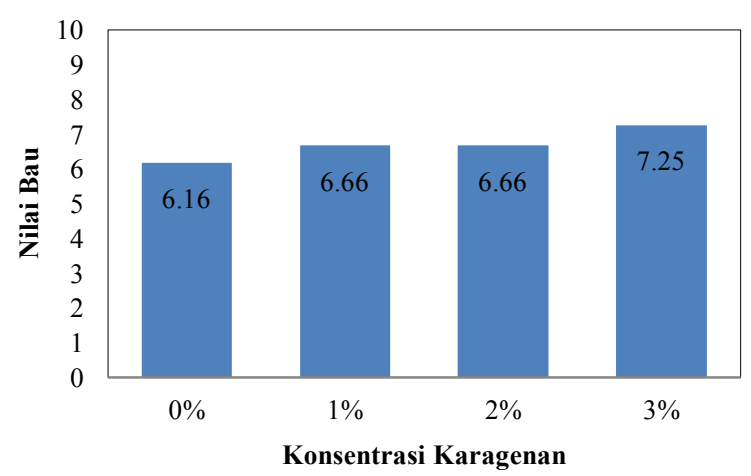

Gambar 3. Hasil penilaian panelis terhadap nilai organoleptik (aroma) bakso ikan tuna.

Berdasarkan Gambar 5, dapat dilihat bahwa penilaian panelis untuk produk bakso dengan aroma terbaik ada pada bakso dengan substitusi karagenan 3\% kemudian bakso dengan substitusi karagenan $2 \%$. Selanjutnya dengan perolehan suara sama dari panelis yaitu bakso dengan substitusi karagenan $1 \%$ dan yang terakhir adalah bakso tanpa penambahan karagenan. Dari grafik di atas, penambahan karagenan tidak terlalu berpengaruh besar terhadap aroma bakso ikan. Hal ini dijelaskan oleh penelitian Handoko (2018) yang menyatakan semakin banyak karagenan yang ditambahkan tidak terlalu mempengaruhi aroma dari otak-otak ikan patin. Hal ini diperkuat lagi oleh Suryaningrum et.al. (2000) yang menyatakan karagenan adalah senyawa hidrokoloid yang diekstraksi dari rumput laut merah jenis Euchema cottonii. Herawati dan Ahza (2005), menjelaskan bahwa hidrokolid pada umumnya tidak mengandung bahan-bahan volatil yang dapat menimbulkan aroma dan warna pada bahan pangan, akan tetapi hidrokoloid dapat menimbulkan efek sinergis pada penambahan cita rasa ke dalam emulsi. Dari grafik diketahui nilai rata-rata 6-7 artinya penilaian panelis terhadap produk adalah agak suka-suka, nilai dari produk bakso dengan konsentrasi karagenan $3 \%$ sudah memenuhi syarat SNI yaitu 7 .

\section{Kenampakan}

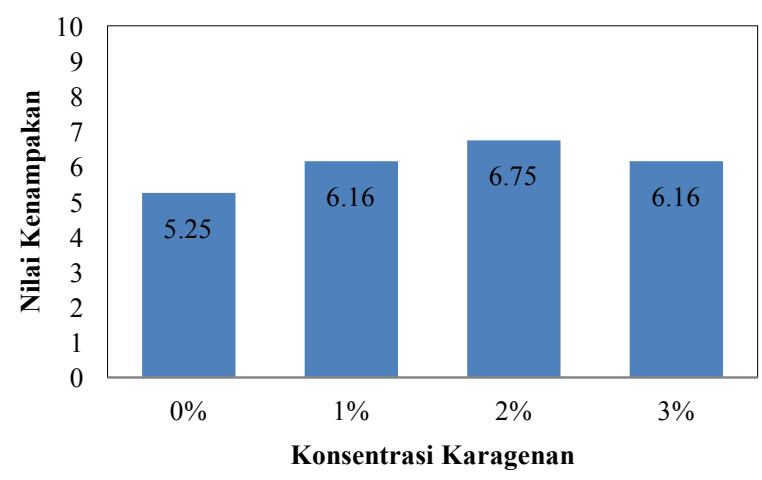

Gambar 4. Hasil penilaian panelis terhadap nilai organoleptik (kenampakan) bakso ikan tuna. 
Berdasarkan Gambar 4, dapat dilihat bahwa penilaian panelis untuk produk pada bakso dengan substitusi karagenan 2\%. Kemudian yaitu bakso dengan substitusi karagenan 3\%. Selanjutnya dengan jumlah penilaian yang sama oleh panelis yaitu bakso dengan substitusi karagenan $1 \%$ dan yang terakhir adalah bakso tanpa tambahan karagenan.

Soekarto, 1985 dalam Ariffianto, 2010 menyatakan, diantara sifat-sifat produk pangan yang paling cepat menarik perhatian konsumen dan paling cepat memberi kesan disukai atau tidak disukai adalah warna. Arti dan bakso dengan kenampakan terbaik ada peranan warna pada produk pangan antara lain sebagai perinci jenis, tanda-tanda kerusakan, petunjuk tingkat mutu dan pedoman proses pengolahan.

Pada penelitian ini, bakso tanpa tambahan karagenan memperoleh nilai terkecil dari segi penampakan. Hal ini dikarenakan karagenan pada produk bakso dapat mengikat air hingga meningkatkan kekenyalan dan membuat tampilan bakso menjadi halus. Namun hak ini tidak sesuai dengan penelitian Ariffianto (2010) yang menyatakan bahwa penambahan karaginan kurang dari $2 \%$ pada bakso mampu meningkatkan tekstur dan tampilan bakso.

Kenampakan bakso ikan tuna yang dihasilkan semuanya memiliki warna putih keabuabuan, bentuknya bulat namun tidak bulat sempurna dan permukaannya tidak terlalu halus namun masih bisa diterima oleh panelis. Pada penelitian ini, kenampakan bakso ikan yang paling disukai adalah bakso ikan dengan konsentrasi $2 \%$, kemudian dengan perolehan nilai yang sama yaitu pada bakso ikan dengan konsentrasi karagenan 1\% dan 3\%. Sedangkan dengan nilai terkecil yaitu bakso ikan tanpa penambahan karagenan. Panelis memiliki tingkat kesukaan yang hampir sama terhadap kenampakkan bakso ikan tuna yang ditambahkan tepung karaginan. Hasil ini sejalan dengan hasil penelitian Candra et.al. (2014) tentang penambahan karaginan pada bakso ikan nila merah yang juga menunjukkan hasil yang tidak berbeda nyata pada kriteria kenampakan. Penambahan tepung karagenan tidak mempengaruhi kenampakkan bakso ikan tuna diduga karena tepung karagenan yang memiliki warna yang putih, sehingga penambahan karaginan pada penelitian ini yang dengan konsentrasi yang tidak berbeda jauh tidak terlalu berpengaruh pada kenampakkan bakso ikan tuna.

Dewi (2007) menyatakan, kenampakan bakso ikan yang baik haruslah berbentuk bulat halus, berukuran seragam, bersih, cemerlang dan tidak kusam. Secara umum bakso ikan tuna hasil penelitian telah memenuhi kriteria tersebut namun bentuknya yang tidak bulat halus dan ukurannya kurang seragam, hal ini mungkin dikarenakan pembentukan bakso ikan tuna ini dilakukan secara manual dengan menggunakan tangan. Meski demikian, kenampakkan bakso ikan tuna masih dapat diterima oleh panelis. Dari grafik diketahui nilai rata-rata 5-6 artinya penilaian panelis terhadap produk adalah netral-agak suka, namun nilai ini memenuhi SNI yaitu rata-rata nilai 7.

\section{Uji pH}

Berdasarkan hasil penelitian, diperoleh nilai rata-rata $\mathrm{pH}$ bakso ikan tuna yang disubstitusi tepung karagenan dengan konsentrasi berbeda.

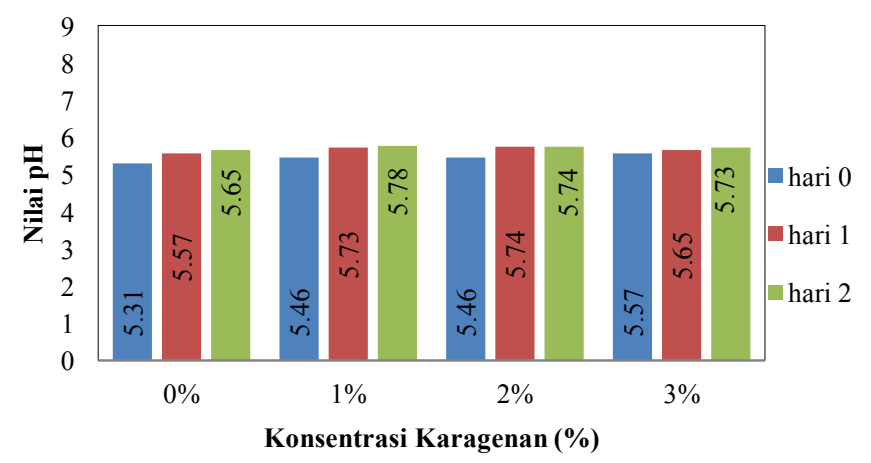

Gambar 5. Hasil pengujian pH bakso ikan tuna pada penyimpanan hari ke 0,1 dan 2 hari pada suhu ruang.

Berdasarkan Gambar 7, dapat dilihat bahwa rata-rata nilai $\mathrm{pH}$ pada produk bakso dengan substitusi karagenan $0 \%, 1 \%, 2 \%$ dan 3\% mengalami kenaikan pada hari 1 dan 2 . Pengukuran $\mathrm{pH}$ bertujuan untuk mengetahui tingkat keasaman bakso ikan gabus yang disebabkan oleh ion hidrogen $(\mathrm{H}+)$. Produk akhir yang mengalami pemasakan dan penggaraman bergantung pada $\mathrm{pH}$ daging. 
Temperatur tinggi meningkatkan laju penurunan $\mathrm{pH}$ sedangkan temperatur rendah menghambat laju penurunan pH (Sudrajat, G. 2007). Hal ini diperkuat lagi dengan pernyataan bahwa daging ikan dan produk olahan ikan yang mempunyai $\mathrm{pH}$ tinggi disebabkan karena timbulnya senyawasenyawa yang bersifat basa seperti amoniak, trimetilamin, dan senyawa-senyawa volatile lainnya, yang juga dapat menurunkan nilai organoleptik dari produk. Proses glikolisis, enzim sangat berperan sampai terbentuknya asam laktat. Hal ini menyebabkan akumulasi asam laktat berjalan lebih lambat sehingga $\mathrm{pH}$ ikan juga meningkat (Munandar,2009).

\section{Uji Kadar Air}

Berdasarkan hasil penelitian, diperoleh nilai rata-rata kadar air bakso ikan tuna yang disubstitusi tepung karagenan dengan konsentrasi berbeda :

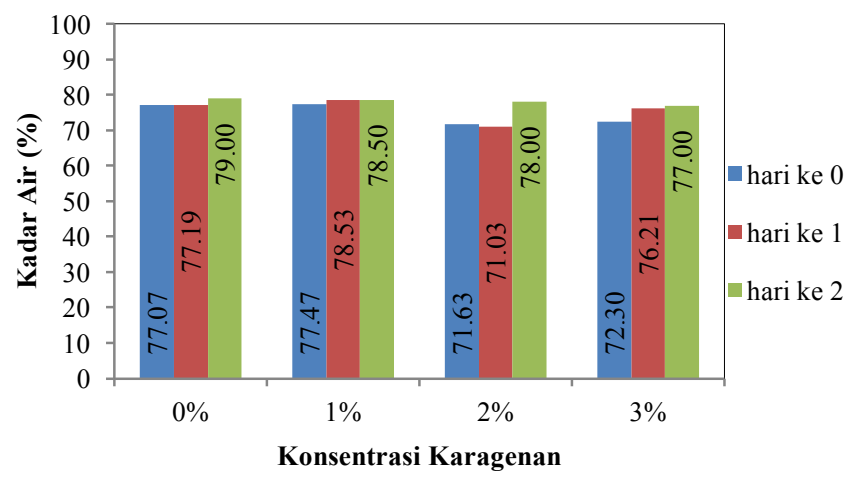

Gambar 6. Hasil pengujian kadar air pada bahan baku pembuatan bakso dan pada bakso ikan tuna penyimpanan hari ke 0,1 dan 2 hari pada suhu ruang.

Dari grafik di atas dapat dilihat bahwa nilai rata-rata kadar air tertinggi pada hari ke 0 adalah $79 \%$ pada bakso ikan tanpa substitusi karagenan dan bakso ikan dengan substitusi $1 \%$ karagenan. Sedangkan nilai rata-rata terendah adalah $77 \%$ pada bakso ikan yang diberi perlakuan 3\% karagenan. Bakso ikan tuna tanpa penambahan karagenan menunjukkan nilai kadar air paling tinggi dibandingkan dengan perlakuan lainnya. Hal ini disebabkan adanya proses pencucian pada ikan dan perebusan pada bakso sehingga dapat meningkatkan kadar air dalam daging ikan. Hal ini terjadi karena pencucian dan perebusan mampu meningkatkan sifat hidrofilik dari daging ikan (Suzuki, 1981). Sedangkan nilai kadar air yang paling rendah ditunjukkan oleh bakso ikan tuna dengan penambahan karaginan 3\%. Hal itu menunjukkan bahwa pada konsentrasi tersebut karaginan mampu mengikat lebih banyak air dan gugus sulfat dan mengikat lebih banyak gugus protein. SNI untuk nilai kadar air pada bakso ikan maksimal 65\% (SNI 7266:2014), hal ini menunjukkan bahwa kadar air bakso ikan tuna dengan substitusi tepung karagenan tidak memenuhi syarat SNI.

Menurut Rohana (2016), pengaruh kadar air sangat penting sekali dalam menentukan daya awet suatu bahan pangan karena kadar air mempengaruhi sifat-sifat fisik (organoleptik, sifat kimia dan kebusukan oleh mikroorganisme). Pada penelitian ini, tampak bahwa bakso ikan yang disimpan hingga 2 hari pada suhu ruang kadar airnya meningkat dari sebelumnya. Menurut Winarno (1980) naiknya kadar air selama penyimpanan diakibatkan adanya pelepasan ikatan $\mathrm{H}$ antara molekul pada saat terjadi pembusukan misalnya : protein akan diurai menjadi basa-basa organik, dan air terikat dapat berubah menjadi air bebas, dengan adanya air bebas dan kadar air meningkat. Faktor yang sangat besar pengaruhnya terhadap daya tahan produk adalah kadar air. Semakin rendah kadar air makin lambat pertumbuhan mikroba sedangkan makin tinggi kadar air makin cepat mikroba berkembang biak sehingga proses pembusukan akan berlangsung lebih cepat (Tendean, 2011).

\section{Total Plate Count (TPC)}

Berdasarkan hasil penelitian, diperoleh nilai rata-rata total bakteri bakso ikan tuna yang disubstitusi tepung karagenan dengan konsentrasi berbeda. 


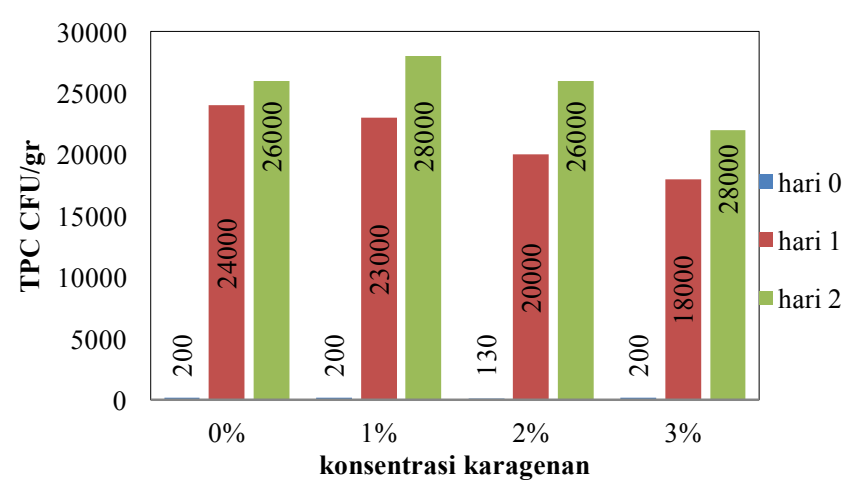

Gambar 7. Hasil pengujian Total Plate Count (TPC) bakso ikan tuna pada penyimpanan hari ke 0, 1 dan 2 hari.

Hasil penelitian, pertumbuhan bakteri paling tinggi terjadi pada hari ke 2. Pada bakso dengan konsentrasi $3 \%$, pertumbuhan bakteri lebih sedikit dibanding dengan bakso dengan konsentrasi karagenan yang lebih rendah. Hal ini menunjukkan bahwa penambahan karagenan menyebabkan pertumuhan bakteri yang lebih sedikit dibandingkan bila tanpa pemberian karagenan. Hal ini sesuai dengan pendapat Shanmugam dan Mody, (2002), bahwa karagenan merupakan senyawa polisakarida yang dihasilkan dari beberapa jenis alga merah yang memiliki sifat antibakteri.

Penyimpanan produk pada hari 1 dan 2 sudah terjadi peningkatan nilai koloni bakteri pada produk bakso yang disimpan pada suhu ruang, hal ini disebabkan bakteri dan kapang mulai bertumbuh dan berkembang biak. Menurut SNI 7266:2014 tentang Batas Maksimum Cemaran Mikroba dalam produk bakso ikan, batas maksimum nilai TPC dalam produk olahan ikan adalah $1,0 \times 10^{5} \mathrm{koloni} / \mathrm{gram}$. Pada produk bakso yang dibuat, produk yang memenuhi syarat mutu bakso ikan yang direkomendasikan adalah produk dengan masa penyimpanan 0 hari.

Pada penyimpanan 1 hari dan 2 hari sudah terjadi peningkatan nilai koloni bakteri pada produk bakso yang disimpan pada suhu ruang, hal ini disebabkan bakteri dan kapang mulai bertumbuh dan berkembang biak. Adanya peningkatan kadar air untuk bakso pada hari ke 1 dan ke 2 diduga karena proses denaturasi protein. Menurut Buckle et. al., (1987) denaturasi, berarti struktur protein berubah dari bentuk unting ganda yang kuat menjadi kendur dan terbuka, sehingga memudahkan bagi enzim pencernaan untuk menghidrolisis dan memecahkannya menjadi asamasam amino. Hal ini sangat mempengaruhi kualitas bakso, seperti tekstur, karena tekstur sangat dipengaruhi oleh kadar air. Hal ini kemungkinan karena jumlah bakteri patogen telah meningkat lebih banyak. Dengan semakin banyaknya jumlah bakteri, maka air yang dihasilkan dari metabolisme akan memberikan sumbangan kadar air dalam bakso. Aktivitas bakteri memanfaatkan protein untuk metabolisme, yang menyebabkan penurunan kadar protein atau terjadinya degradasi protein pada penyimpanan suhu kamar. Hal ini diperkuat dengan pendapat Suzuki (1981) yang menyatakan penurunan ini disebabkan adanya enzim protease yang mengkatalisis protein menjadi polipeptida dan enzim peptidase yang mengkatalisis peptida menjadi peptida sederhana dan asam amino. Penyimpanan pada suhu kamar dapat mempercepat kerusakan makanan karena jumlah bakteri meningkat. Kerusakan bahan makanan yang disebabkan oleh mikroorganisme terjadi karena mikroorganisme tersebut memanfaatkan komponen dalam bahan pangan tersebut berkembang biak dan melakukan metabolisme, sehingga bahan makanan mengalami perubahan bau dan rasa yang menyebabkan bahan makanan tidak dapat dikonsumsi lagi.

\section{KESIMPULAN DAN SARAN}

\section{Kesimpulan}

Penambahan karagenan dengan konsentrasi berbeda berpengaruh terhadap nilai organoleptik, kadar air, $\mathrm{pH}$ dan TPC. Berdasarkan hasil penelitian, bakso ikan tuna dengan penambahan konsentrasi $2 \%$ merupakan produk yang terbaik dengan nilai rata-rata nilai organoleptik: 6,58; kadar air: 71,63; pH: 5,46; dan TPC: 2,6 $\times 10^{4}$. Kadar air pada bakso tidak memenuhi syarat SNI, yaitu maksimal $65 \%$ Total bakteri pada bakso masih memenuhi persyaratan 
mutu SNI, yaitu $1 \times 10^{5}$. Perlu penelitian lanjutan suhu penyimpanan produk terhadap mutu bakso ikan tuna (Thunnus albacares). Perlu waktu yang lebih lama pada waktu pencampuran agar penampakan bakso yang dihasilkan lebih halus.

\section{DAFTAR PUSTAKA}

Anggadiredja, J.T. 2006. Rumput Laut. Penebar Swadaya. Jakarta.

Ariffianto, T. 2010. Karakteristik Bakso Ikan Nila Dengan Penambahan Karaginan Semi murni. [Skripsi]. Fakultas Perikanan dan Ilmu Kelautan. Institut Pertanian Bogor.

Buckle, K.A.,1987. Ilmu Pangan. Universitas Indonesia Press. Jakarta.

Dewi, I. A. Imam S. 2007. Aplikasi Metode AHP (Analytical Hierarchy Process) dalam Menganalisis Faktor-Faktor yang Mempengaruhi Mutu Bakso Ikan Kemasan. Jurnal Teknologi Pertanian. 8 (1): 19-25.

Candra, F. N., Riyadi, P.H., Wijayanti, I. 2014. Pemanfaatan Karagenan (Euchema cottoni) Sebagai Emulsifier Terhadap Kestabilan Bakso Ikan Nila (Oreochromnilotichus) Pada Penyimpanan Suhu Dingin. Jurnal Pengolahan dan Bioteknologi Hasil Perikanan. Volume 3, Nomor 1, Tahun 2014, Halaman 167-176.

Dwi, Wiwin. 2008. Isolasi dan Karakterisasi Natrium Alginant dari Rumput Laut Sargassum sp untuk Pembuatan Bakso Ikan Tenggiri (Scomberomus commerson). [Skripsi]. Universitas Sebelas Maret. Surakarta.

Handoko, Danny. 2018. Pengaruh Penambahan Karagenan Terhadap Mutu Otak-Otak Ikan Patin (Pangasius hypopthalmus). [Skripsi] Fakultas Perikanan dan Ilmu Kelautan. Universitas Riau. Pekanbaru

Herawati, dan Ahza. 2005. Penentuan Umur Simpan Pada Produk Pangan. Balai Pengkajian Teknologi Pertanian. Jawa Tengah.

Munandar. Aris. 2009. Kemunduran Mutu Ikan Nila (Oreochromis niloticus) Pada Penyimpanan Suhu Rendah dengan Perlakuan Cara Kematian dan Penyiangan. [Skripsi] Institut Pertanian Bogor.

Naa, Yance. 2011. Mutu Sensori BaksoIkan Asap Cair Yang Disimpan Pada Suhu Kamar Dengan Bahan Pengemas. [Skripsi]. Fakultas Perikanan dan Ilmu Kelautan. Universitas Sam Ratulangi. Manado

Nurhuda, H. S., Junianto, Rochima, E. 2017. Penambahan Tepung Karaginan Terhadap Tingkat Kesukaan Bakso Ikan Manyung. Jurnal Perikanan dan Kelautan Vol. VIII No. 1 /Juni 2017 (157-164).

Poluakan, O. A., Dien, H. A., Ijong, F. G,. 2015. Mutu Mikrobiologis Bakso Ikan yang Direndam Asap Cair, Dikemas Vakum, Dipasteurisasi dan Disimpan pada Suhu Dingin. Jurnal Media Teknologi Hasil Perikanan Vol. 3, No. 2, Agustus 2015.

Rohana, M. L., Berhimpon, S., Palenewen, J. Ch. V., 2016. Keberadaan Mikroba pada Bakso Ikan Asap Cair, yang Dikemas dalam Retortable Pouch, Dipasteurisasi dan Disimpan pada Temperatur Ruang. Jurnal Media Teknologi Hasil Perikanan Vol 4, No 2, Agustus 2016.

Shanmugam, M. and Mody, K.H. 2000. Heparinoid-active Sulphated Polisaccharides from Marine Algae as Potential Blood Anticoagulant Agents. Marine Algae \& Marine Environment Discipline. India: Central Salt \& Marine Chemicals Research Institute.

Suryaningrum., D., Murdinah., Arifin M. 2000. Penggunaan Kappa-karaginan Sebagai Bahan Penstabil pada Pembuatan Fish Meat Loaf dari Ikan Tongkol (Euthynnus affinis). Jurnal Penelitian Perikanan Indonesia. Vol: 8/6.

Suzuki T. 1981 Fish \& Krill Proteins. Processing Technology. London: Appl. Sci Publ.

Tendean, Elpira. 2011. Kajian Mutu Bakso Ikan Yang Disubstitusi Dengan Nutrijel Yang Disimpan Pada Suhu Rendah. [Skripsi]. Fakultas Perikanan dan Ilmu Kelautan. Universitas Sam Ratulangi. Manado.

Wibowo S. 1999. Pembuatan Bakso Ikan dan Bakso Daging. Penebar Swadaya. Jakarta.

Winarno, F.G. 1990. Teknologi Pengolahan Rumput Laut. PT Gramedia Pustaka Utama. Jakarta. 